\title{
Natalia Daśko
}

Nicolaus Copernicus University in Toruń, Poland

\section{Natalia Daśko (rev.): Enforcement of Intellectual Property Rights through Border Measures: Law and Practice in the EU, Olivier Vrins and Marius Schneider (eds.), Oxford University Press, Oxford 2012, pp. cxx +1124.}

Each year the European Commission publishes an annual report describing the customs detentions of articles suspected of infringing intellectual property rights (IPR) such as trademark, design and model right, patent, copyright and plant variety. Results of customs controls at the European Union (EU) external borders enable to measure the scale of customs actions to enforce IPR. In 2012, more than 90,000 detention cases were registered by customs ${ }^{1}$. Customs play a significant role in identifying and detaining goods suspected of violating IPR before they enter the internal market. EU legal framework for the enforcement of border measures and its implementation on national levels are subject matter of Enforcement Of Intellectual Property Rights Through Border Measures: Law And Practice In The EU, edited by Olivier Vrins and Marius Schneider, in its second edition.

Customs however cannot check everything, and only a tiny percentage of all goods crossing the EU's external borders are subject to customs controls. Although the statistics can only show the "tip of the iceberg", these figures contain interesting insights and reveal trends which are broadly discussed in this book.

Global levels of counterfeiting and piracy remain high; International Chamber of Commerce (ICC) indicates that counterfeiting accounts for between $5-7 \%$ of world trade, worth an estimated 600 billion dollars a year ${ }^{2}$. Not surprising therefore, that the heading that prefaces the remarks made in the foreword of book is Counterfeiting and Piracy: A $21^{\text {st }}$ Century Pandemic. On the next pages we find other descriptions like "scourge", "gangrene" or "plague" which are fully reasonable due to all consequences of phenomena of piracy and counterfeiting.

Counterfeiting and piracy destabilize businesses in all sectors and devastates IPR industries. Hampering investment in research and development as well as creativity should be regarded as one of the most important impacts of this phenomenon. Moreover, revenues, companies' reputation and value of the trademarks suffer. It should be

1 Report on EU customs enforcement of intellectual property rights. Results at the EU border 2012 , p. 7.

2 http://www.iccwbo.org/products-and-services/fighting-commercial-crime/counterfeiting-intelligence-bureau/, [Access date: 06.06.2014]. 